\title{
ISOLATION, IDENTIFICATION AND PHYSIOLOGICAL STUDY OF LACTOBACILLUS FERMENTUM LPB FOR USE AS PROBIOTIC IN CHICKENS
}

\author{
Elizete de F. Reque'; Ashok Pandey'; Sebastião G. Franco²; Carlos R. Soccol ${ }^{1 *}$ \\ 'Laboratório de Processos Biotecnológicos, Departamento de Engenharia Quimica, Universidade Federal do Paraná, \\ Curitiba, PR, Brasil. ${ }^{2}$ Departamento de Zootecnia, Universidade Federal do Paraná, Curitiba, PR, Brasil
}

Submitted: July 27, 1999; Returned to authors for corrections: January 10, 2000; Approved: November 06, 2000.

\begin{abstract}
Studies were carried out to isolate and identify microorganisms for probiotic use for chickens. Selection of strains included various criteria such as agreement with bio-safety aspects, viability during storage, tolerance to low $\mathrm{pH} /$ gastric juice, bile, and antimicrobial activity. The strains were isolated from the crop, proventriculus, gizzard, ileum and caeca of chicken. Decimal dilution of the contents of these segments were mixed with MRS medium and incubated for $48 \mathrm{~h}$ at $37^{\circ} \mathrm{C}$ under anaerobiosis. The identity of the culture was based on characteristics of lactobacilli as presented in the Bergey's Manual of Determinative Bacteriology, carrying out bacterioscopy (morphology), Gram stain, growth at 15 and $45^{\circ} \mathrm{C}$, and fermentation of different carbon sources. Based on these criteria, Lactobacillus fermentum LPB was identified and tested for probiotic use for chickens. The isolate was evaluated for poultry feeds supplement. The results showed that in comparison to the presence and effects of antibiotics, L. fermentum LPB implantation resulted in a similar effect as that of antibiotics manifested by feed efficiency in growth of chicks.
\end{abstract}

Key words: probiotic, poultry, Lactobacillus fermentum

\section{INTRODUCTION}

The history of live microbial feed supplements goes back to thousands of years. Probably the first foods that contained living microorganisms were the fermented milks that are recorded in the Old Testament $(8,12)$. The beneficial effects of yoghurt were put on a scientific basis in 1907 by Elie Metchnikoff, the work that is regarded as the birth of probiotics (8). The word probiotic has been derived from the Greek language meaning "for life" and has had several different meanings over the years. The definition actually accepted presently was formulated by Fuller in 1989 (7). He redefined probiotics as 'A live microbial feed supplement which beneficially affects the host animal by improving its intestinal microbial balance.'

Probiotics control intestinal pathogens by production of antibacterial compounds, including lactic and acetic acid and antibiotic-like substances, competition for nutrients and adhesion sites, increased and decreased enzyme activity, increased antibody levels and increased macrophage activity (11).

In the selection of microbial strains for probiotic use, several criteria must be considered, which include bio-safety aspects, production and processing aspects, the method of administering the probiotic, the location on/in the body where the microorganisms of the probiotic product must be active, survival and/or colonization in the host, and the tolerance for bile $(8,9)$. Lactic acid bacteria (LAB) have generally been considered as good probiotic organisms and the genus currently being used in probiotic preparations are Lactobacillus, Bifidobacterium and Streptococcus (Enterococcus) $(13,18)$.

Tortuero (19) reported that the addition of Lactobacillus acidophilus to poultry feed produced similar effects to antibiotics, manifested by increase in weight and better feed efficiency.

The aim of the present work was to isolate and identify micro-organisms for probiotic use for chickens. Studies also

\footnotetext{
* Corresponding author. Mailing address: Laboratório de Processos Biotecnológicos, Departamento de Engenharia Química, Universidade Federal do Paraná, CEP 81531-970, Curitiba, PR, Brasil. Fax (+5541) 266-0222. Email soccol@engquim.ufpr.br
} 
included the evaluation of an experimental probiotic for chickens.

\section{MATERIALS AND METHODS}

Isolation and identification of microbial strains. The microbial strains were isolated from contents of crop, proventriculus, gizzard, ileum and caeca of an adult chicken (Gallus domesticus), fed without antibiotics. Decimal dilution of these samples were mixed with MRS medium (Oxoid) and incubated at $37^{\circ} \mathrm{C}$ for $48 \mathrm{~h}$ under anaerobiosis $(10,17)$. Pure cultures were maintained in MRS agar at $4^{\circ} \mathrm{C}$ for short-term use and lyophilised for preservation. Selection of strains was made in agreement with bio-safety aspects, bacterioscopy (morphology) (optical microscope, without contrast phase), Gram stain, viability during storage at $4{ }^{\circ} \mathrm{C}$ and antimicrobial activity $(10,17)$.

The identity of the cultures was based on the characteristics of the lactobacilli as described in Bergey's Manual of Determinative Bacteriology (2), fermentation of different carbon sources (API $50 \mathrm{CHL}$, BioMérieux), gas production from glucose, growth at different temperatures, tolerance to inhibitory substances such as bile (Sigma), phenol (Merck), and sodium chloride (Biotec) (3).

Antimicrobial activity. Sterile MRS broth (pH 6.0) was inoculated with $1 \%\left(10^{7} \mathrm{cfu} / \mathrm{ml}\right)$ level of an actively growing culture of each isolate from chicken and incubated at $37^{\circ} \mathrm{C}$ for $24 \mathrm{~h}$. To obtain the test materials (compounds produced by the microbial cultures having antimicrobial activity), fermented MRS broth was centrifuged $(20,000 \mathrm{~g}$ for $15 \mathrm{~min})$ to remove the microbial cells. The resulting liquid was dried under vacuum using a $45^{\circ} \mathrm{C}$ water bath and a rotary evaporator, re-suspended in one-fifth the original volume of water and filtered through sterile $0.45 \mathrm{~mm}$ membrane filters.

Two control test materials were also prepared using uninoculated MRS medium. The $\mathrm{pH}$ of the medium in one tube was adjusted to 6.0 (the initial $\mathrm{pH}$ of the MRS broth) and the other to $\mathrm{pH} 4.0$ (the final $\mathrm{pH}$ final after fermentation) using formic acid $(1,15)$.

Test organisms. To detect antimicrobial activity of the preparations the following organisms grown in nutrient broth at $37^{\circ} \mathrm{C}$ for $24 \mathrm{~h}$ were used: Escherichia coli (ATCC 11229), Salmonella typhimurium (ATCC 14028) and Staphylococcus aureus (ATCC 14458).

Bioassays. Antimicrobial activity was quantitated by a ditch assay (16) using the test organisms. Actively growing culture of the test organisms were mixed at a $2.5 \%\left(2.5 \times 10^{7} \mathrm{cfu} / \mathrm{ml}\right)$ with melted nutrient agar poured in sterile Petri dishes and allowed to solidify. A one-cm wide ditch was cut in the agar across the centre of the dish. The test material obtained from the isolated cultures was diluted in an equal volume of melted bacteriological agar $\left(0.012\right.$ g.L $\left.\mathrm{L}^{-1}\right)$ and then $0.2 \mathrm{ml}$ of the mixture was pipetted into the ditch. When the mixture solidified, the plates were first incubated at $4^{\circ} \mathrm{C}$ for $60 \mathrm{~min}$ to allow the test material to diffuse in the agar and then incubated at $37^{\circ} \mathrm{C}$ for $18 \mathrm{~h}$. After incubation, the diameter of the clear zone was measured in centimetres from the centre of the well.

Gas production from glucose. MRS broth containing $0.2 \%$ $(\mathrm{v} / \mathrm{v})$ of $1.5 \%$ aqueous solution of bromocresol-purple was dispensed into tubes containing inverted Durham tubes. After inoculation with $1 \%\left(10^{7} \mathrm{cfu} / \mathrm{ml}\right)$ of the organism under test and incubated at $37^{\circ} \mathrm{C}$ and observed after $24 \mathrm{~h} \mathrm{(3)}$.

Effect of temperature. Isolated cultures were inoculated at $1 \%\left(10^{7} \mathrm{cfu} / \mathrm{ml}\right)$ in MRS broth and incubated at 15,37 and $45^{\circ} \mathrm{C}$ for $24 \mathrm{~h}$ and monitored for growth by measuring the absorbance at $540 \mathrm{~nm}$.

Tolerance to inhibitory substances. MRS agar (4) containing 0.3 or $10 \%$ bile, 0.3 or $0.4 \%$ phenol, and 4 or $8 \%$ sodium chloride was inoculated with $1 \%\left(10^{7} \mathrm{cfu} / \mathrm{ml}\right)$ of the organism under test. The pour plate method was used. The plates were incubated in a GasPak jar (PROBAC) at $37^{\circ} \mathrm{C}$ for 72 $\mathrm{h}$ and then the colonies (cfu) counted.

Effect of agitation. To investigate the effect of agitation on bacterial growth, actively growing cultures were inoculated at $1 \%\left(10^{7} \mathrm{cfu} / \mathrm{ml}\right)$ in MRS broth and incubated at $37^{\circ} \mathrm{C}$ under (a) agitation at $200 \mathrm{rpm}$ and (b) static conditions. Samples were taken aseptically at time zero and at $2 \mathrm{~h}$ intervals thereafter for $8 \mathrm{~h}$. Total populations were determined by pour plate method by incubating the plates at $37^{\circ} \mathrm{C}$ for $48 \mathrm{~h}$ anaerobically.

Evaluation of probiotic activity. The experiment was carried out with chicks to evaluate the influence of $L$. fermentum LPB at $21,35,42$ and 49 days of life on food efficiency. A total of 1,600 broiler chicks ( 800 males and 800 females) were divided in 32 groups, each comprising 50 broilers, subjected to four different programmes with four replicates. The programmes were: I) food with antibiotics (avilamicina $6 \mathrm{mg} / \mathrm{kg}$ and olaquindox $60 \mathrm{mg} / \mathrm{kg}$ of feed) without probiotic in drinking water; II) no antibiotic in the feed and no probiotic in drinking water; III) Lactobacillus fermentum LPB $\left(10^{6} \mathrm{cfu} / \mathrm{ml}\right)$ in drinking water in the first and fifteenth day of life, and no antibiotic in the feed, IV) Lactobacillus acidophilus $\left(3 \times 10^{5}\right.$ $\mathrm{cfu} / \mathrm{ml})$, L. fermentum LPB $\left(3 \times 10^{5} \mathrm{cfu} / \mathrm{ml}\right)$, L. plantarum $\mathrm{A}_{6}$ $\left(3 \times 10^{5} \mathrm{cfu} / \mathrm{ml}\right)$, Saccharomyces boulardii $\left(3 \times 10^{5} \mathrm{cfu} / \mathrm{ml}\right)$ in drinking water in the first and fifteenth day of life and no antibiotic in the feed.

During the experiment, feed and water were administered ad libitum. The composition of the diet was as described by Franco (6).

Three strains were used as reference: (a) Lactobacillus acidophilus CCT 0329, from the Culture Collection of the Fundação Tropical de Pesquisa e Tecnologia André Tosello, Campinas-SP; (b) L. plantarum $\mathrm{A}_{6}$, from Laboratoire de Biotechnologie, Montpellier, France; (c) Saccharomyces boulardii, from Floratil-MERCK. 
Statistical Analysis. Means of the different programmes were subjected to Newman Keuls test (5) a probability level of 0.05 .

\section{RESULTS AND DISCUSSION}

Twenty-two strains were isolated on MRS medium from different segments of the alimentary tract of chicken. Two of them, designated as CCI1A (from caeca), and 3-2006 (from crop) were selected for further investigations.

Antimicrobial activity. Fig 1 shows the size of inhibition zones obtained for E. coli, S. typhimurium and S. aureus. Inhibition zones in all cases were bigger or similar than the control at $\mathrm{pH}$ 6. However, when compared with the inhibition zones obtained with the other control, $\mathrm{pH} 4$, strain CCI1A was smaller or similar in case of E. coli and S. aureus. Thus, these effects were apparently due to a pH effect (result of lactic acid production) and not to the production of any antimicrobial agent present in the materials tested. However, in case of $S$. typhimurium the inhibition zone produced by strain CCI1A was bigger than by of the controls $\mathrm{pH} 4$. This suggested the strain CCI1A produced some antimicrobial activity, which was effective against $S$. typhimurium but not against $E$. coli or $S$. aureus. There are literature reports describing that the inhibition of microbial growth resulted from the presence of the lactic acid produced, or due to the production of other antimicrobial compounds showing inhibitory properties (11). Pandey et al. (14) also noted the $\mathrm{pH}$ effect in fermentation analysis (due to the production of lactic acid) during their study with 23 strains of lactic acid bacteria on their nutritional requirements of iron.

Strain CCI1A showed higher inhibitory activity than 32006 and was selected for more detailed studies.
Identification of the strain. The strain CCI1 A was identified as Lactobacillus fermentum (API 50 CHL, BioMérieux) and designated as L. fermentum LPB. It showed short, single and paired square bacilli in MRS broth after $24 \mathrm{~h}$ of incubation at $37^{\circ} \mathrm{C}$ in anaerobiosis. The colonies in MRS agar were smooth and convex.

L. fermentum LPB produced gas from glucose, grew at $45^{\circ} \mathrm{C}$ but poorly at $15^{\circ} \mathrm{C}$, in accordance with Bergey's Manual (2). The strain tolerated 0.3 and $10 \%$ bile, 0.3 and $0.4 \%$ phenol and $4 \%$ but not $8 \% \mathrm{NaCl}$ (Fig. 2). Bile tolerance has been described as an important factor for the survival and growth of LAB in the intestinal tract (9). Growth of the strain was better under static conditions than stirred (Fig. 3), suggesting that the strain was microaerophilic, it needed reduction of oxygen grade, probably on account of the sensibility of yours enzyme in strong conditions of oxidation.

Probiotic activity evaluation. Feed conversion index are shown in Tables 1, 2, 3 and 4. It can be observed from Table 1 that programmes 1,3 and 4 had better feed conversion index than programme 2 (control). Data from Tables 2, 3 and 4 were not statistically different and were similar to those reported by Tortuero (19). Data from Tables 3 and 4 showed that better feed conversion index for males. Franco (6) and Wöhlke (20) reported similar results. The results of the experiments showed that substitution of antibiotic by probiotic did not affect feed efficiency, thus paving the way for substitution of antibiotics by probiotics.

The strain of Lactobacillus fermentum LPB isolated from caeca of chicken in this study showed antimicrobial activity and tolerance to bile. It also showed similar effects to antibiotics in the feed. It could be a suitable strain for probiotic use for chickens.

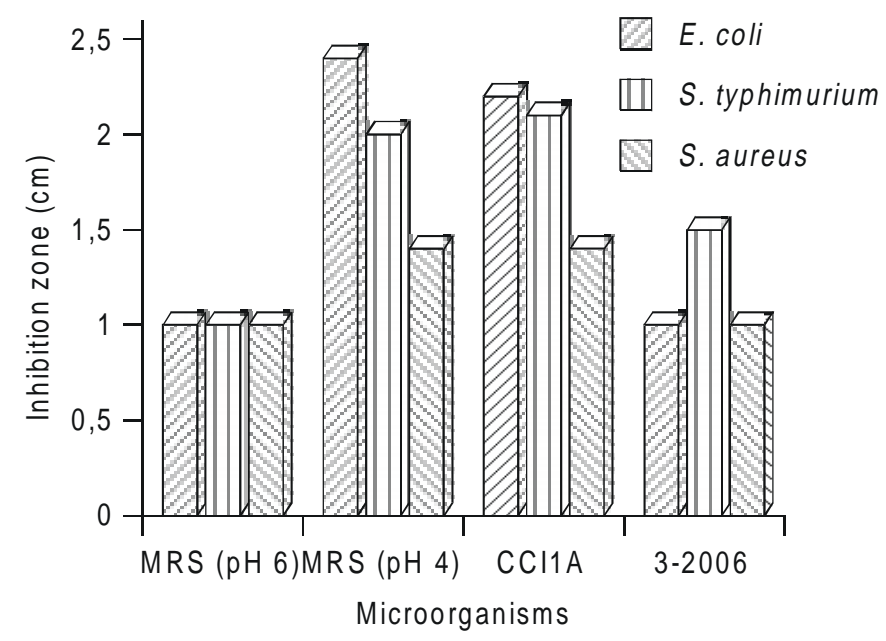

Figure 1. Antimicrobial activity of microorganisms: Strains CCI1 A and 3-2006 and controls (MRS pH 6 and 4), by a ditch assay using the test organisms (Escherichia coli, Salmonella typhimurium and Staphylococcus aureus) incubated at $37^{\circ} \mathrm{C}$ for $18 \mathrm{~h}$. 


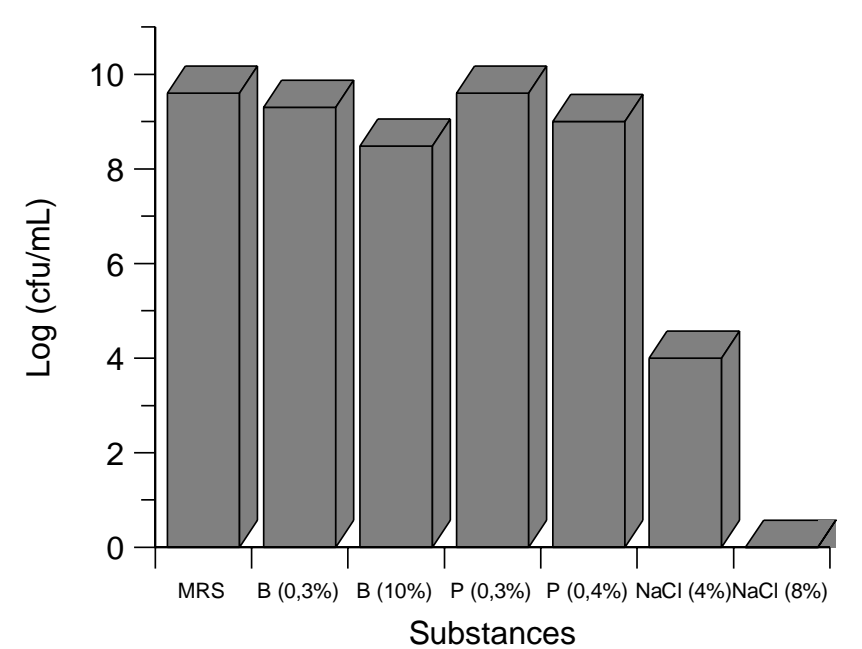

Figure 2. Influence of inhibitory substances add: MRS (control), Bile (B) 0.3 and $10 \%$, Phenol (P) 0.3 and $0.4 \%, \mathrm{NaCl} 4$ and $8 \%$, on the growing of Lactobacillus fermentum LPB in MRS agar incubated at $37^{\circ} \mathrm{C}$ for $72 \mathrm{~h}$ anaerobically.

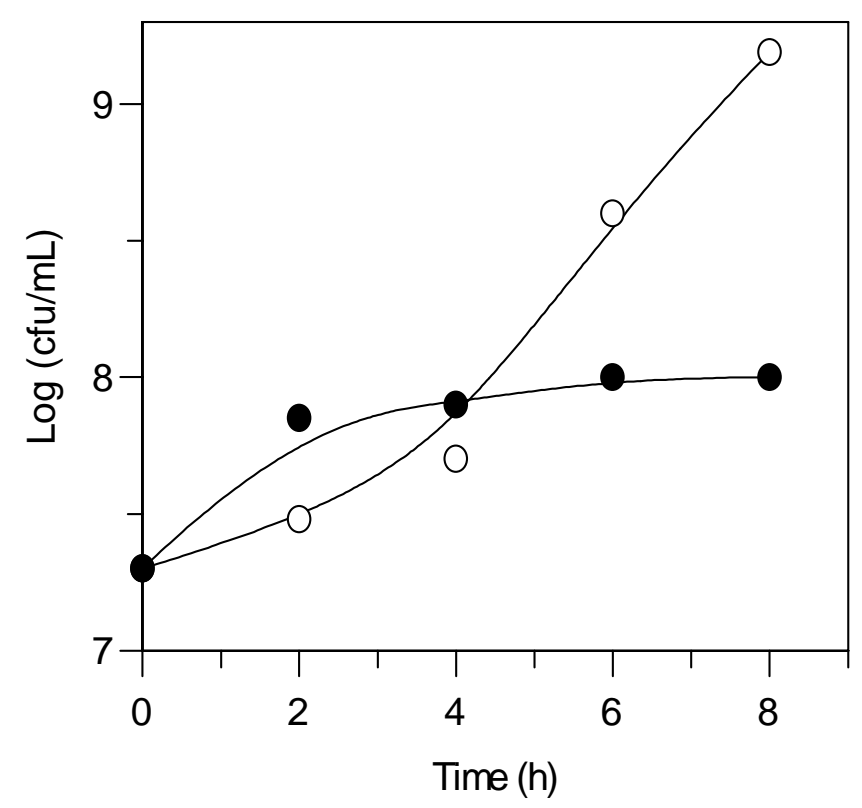

Figure 3. Influence of agitation at $200 \mathrm{rpm}$ (1) and static conditions (m) on the growing of Lactobacillus fermentum LPB in MRS broth incubated at $37^{\circ} \mathrm{C}$.
Table1. Feed conversion index at 21 days of age

\section{Programmes}

\begin{tabular}{|c|c|c|c|c|c|}
\hline Sex & 1 & 2 & 3 & 4 & Mean \\
\hline Male & 1.4855 & 1.5595 & 1.4733 & 1.4993 & 1.5044 \\
\hline Female & 1.4475 & 1.5730 & 1.5428 & 1.5578 & 1.5302 \\
\hline Mean & $1.4665^{\mathrm{a}}$ & $1.5663^{\mathrm{b}}$ & $1.5080^{\mathrm{ab}}$ & $1.5285^{a b}$ & \\
\hline
\end{tabular}

${ }^{a, b}$ Means with no common superscripts differ significantly by test of Newman Keuls (probability level of 0.05).

Table 2. Feed conversion index at 35 days of age

\section{Programmes}

\begin{tabular}{lccccc} 
Sex & 1 & 2 & 3 & 4 & Mean \\
\hline Male & 1.7270 & 1.7500 & 1.6928 & 1.6953 & 1.7163 \\
Female & 1.7265 & 1.9000 & 1.7040 & 1.7823 & 1.7782 \\
Mean & 1.7267 & 1.8250 & 1.6984 & 1.7387 & - \\
\hline
\end{tabular}

${ }^{\mathrm{a}, \mathrm{b}}$ Means with no common superscripts differ significantly by test of Newman Keuls (probability level of 0.05).

Table 3. Feed conversion index at 42 days of age

\section{Programmes}

\begin{tabular}{lccccc} 
Sex & 1 & 2 & 3 & 4 & Mean \\
\hline Male & 1.8900 & 1.8720 & 1.8003 & 1.8670 & $1.8573^{\mathrm{a}}$ \\
Female & 1.8905 & 1.9408 & 1.9108 & 1.9218 & $1.9159^{\mathrm{b}}$ \\
Mean & 1.8902 & 1.9064 & 1.8555 & 1.8944 & - \\
\hline
\end{tabular}

a,b Means with no common superscripts differ significantly by test of Newman Keuls (probability level of 0.05).

Table 4. Feed conversion index at 49 days of age

\section{Programmes}

\begin{tabular}{lccccc} 
Sex & 1 & 2 & 3 & 4 & Mean \\
\hline Male & 2.0168 & 1.9975 & 1.9660 & 1.9845 & $1.9912^{\mathrm{a}}$ \\
Female & 2.0300 & 2.0858 & 2.0707 & 2.0595 & $2.0615^{\mathrm{b}}$ \\
Mean & 2.0234 & 2.0416 & 2.0183 & 2.0220 & - \\
\hline
\end{tabular}

a,b Means with no common superscripts differ significantly by test of Newman Keuls (probability level of 0.05). 


\section{RESUMO}

\section{Isolamento, identificação e estudos fisiológicos de Lactobacillus fermentum LPB para uso como probiótico em frangos de corte}

O nosso trabalho teve como proposta o isolamento e identificação de microrganismos para uso como probiótico em aves. As espécies foram selecionadas de acordo com aspectos de biosegurança, viabilidade durante a estocagem, tolerância a $\mathrm{pH}$ baixo, suco gástrico, bile e atividade antimicrobiana. As espécies foram isoladas do papo, proventrículo, moela, íleo e ceco de frango. Os conteúdos destes segmentos foram diluídos e semeados em meio MRS e incubados por $48 \mathrm{~h}$ a $37^{\circ} \mathrm{C}$ em anaerobiose. A identificação das culturas foi realizada de acordo com as características de Lactobacillus presentes no Manual Bergey's, como bacterioscopia (morfologia), coloração de Gram, crescimento a 15 e $45^{\circ} \mathrm{C}$ e fermentação de diferentes fontes de carbono. Baseado nestes critérios Lactobacillus fermentum LPB foi identificado e testado para uso como probiótico em frangos. O isolado bacteriano foi avaliado como suplemento alimentar para frangos de corte. Os resultados mostraram que, em comparação com a presença e efeitos de antibióticos, a implantação de $L$. fermentum LPB, resultou em efeitos similares, manifestado por eficiência alimentar durante o crescimento de frangos.

Palavras-chave: probiótico, frango de corte, Lactobacillus fermentum

\section{REFERENCES}

1. Abdel-Bar, N.; Harris, N.D.; Rill, R.L. Purification and properties of an antimicrobial substance produced by Lactobacillus bulgaricus. $J$. Food Sci., 52:411-415, 1987

2. Buchanan, R. E.; Gibbons, N. E. Bergey's Manual of Determinative Bacteriology. 8th ed., Williams \& Wilkins, Baltimore, 1974, p.1268

3. Davis, G. H. G. The classification of Lactobacilli from the human mouth. $J$. Gen. Microbiol., 13:481-493, 1955
4. De Man, J. C.; Rogosa, M.; Sharpe, M.E. A medium for the cultivation of lactobacilli. J. Appl. Bacteriol., 23:130-135, 1960

5. Euclides, R. F. Manual de utilização do programa SAEG (Sistema para análises estatísticas e genéticas). Viçosa: UFV, 1983, p. 59

6. Franco, S. G. Programas de alimentação e fontes de óleo para frangos de corte. Jaboticabal, 1992. Tese (Doutorado em Zootecnia); Universidade Estadual Paulista, Brasil.

7. Fuller, R. Probiotics in man and animals. J. Appl. Bacteriol. 66:365378, 1989

8. Fuller, R. Probiotics: The scientific basis. Chapman \& Hall, London, 1992, p. 398

9. Gilliland, S. E.; Walker, D.K. Factors to consider when selecting a culture of Lactobacillus acidophilus as a dietary adjunct to produce a hypocholesterolemic effect in humans. J. Dairy Sci., 73:905-911, 1990

10. Giraud, E.; Brauman, A; Keleke, S.; Leong, B.; Raimbault, M. Isolation and physiological study of an amylolytic strain of Lactobacillus plantarum. Appl. Microbiol. Biotechnol., 36:379-383, 1991

11. Hose, H.; Sozzi, T. Biotechnology group meeting: probiotics - fact or fiction? J. Chem. Technol. Biotechnol., 51: 539-570, 1991

12. Kroger, M.; Kurmann, J. A.; Rasic, J. L. Fermented milks - past, present, and future. Food Technol., 43:92- 99, 1989

13. Pandey, A. Studies on lactic acid fermentation. PhD Thesis, University of Allahabad, India, 1979.

14. Pandey, A.; Bringel, F.; Meyer, J.-M. Iron requirement and search for siderophores in lactic acid bacteria. Appl. Microbiol. Biotechnol., 40:735-39, 1994

15. Pinto, M. F.; Ponsano, E. H. G.; Castro-Gomez, R.J.H, Antibiose relacionada a cultivo de Lactobacillus acidophilus 1 . Seleção de linhagem e estudo de meio de cultivo alternativo à base de soro de queijo. Arq. Biol. Tecnol., 39: 247-257, 1996.

16. Reddy, G. V.; Shahani, K.M.; Friend, B.A.; Chandan, R.C. Natura antibiotic activity of L. acidophilus and bulgaricus. III. production and partial purification of bulgarican from Lactobacillus bulgaricus. Cultured Dairy Products J., 18:15-19, 1983.

17. Reque, E. F. Isolamento, identificação e estudos fisiológicos da bactéria de ação probiótica (Lactobacillus fermentum LPB) para uso em frangos de corte. Dissertação (Mestrado em Tecnologia Química); Universidade Federal do Paraná. Curitiba, 1999.

18. Sullivan, M. G. O; Thornton, G.; Sullivan, G.C.O; Collins, J.K. Probiotic bacteria: myth or reality? Trends Food Sci. Technol., 3:309$314,1992$.

19. Tortuero, F. Influence of the implantation of Lactobacillus acidophilus in chicks on the growth, feed conversion, malabsorption of fats syndrome and intestinal flora. Poultry Science, Champaign, 52:197-203, 1973.

20. Wohlke, L. F. Utilização do probiótico Bacillus natto como promotor de crescimento na alimentação de frangos de corte. Curitiba, 1992. Dissertação (Mestrado em Ciências Veterinárias); Universidade Federal do Paraná 